\title{
PROBLEMS OF CORPORATE ECONOMICS AND SUSTAINABLE DEVELOPMENT IN THE CONTEXT OF THE SANCTION WORLD ORDER: LIVING STANDARDS AND LIFE QUALITY
}

\author{
Irina A. Zhulega ${ }^{1, a,{ }^{*}}$, Natalya L. Gagulina ${ }^{2, b}$, Alexandr V. Samoylov ${ }^{3, \mathrm{c}}$ and \\ Andrey V. Novikov ${ }^{4, \mathrm{~d}}$ \\ ${ }^{1}$ State University of Aerospace Instrumentation, Institute of Enterprinership Technologies, \\ Bolshaya Morskaya str. 67, Saint Petersburg, 190000, Russia \\ ${ }^{2}$ ITMO University, Faculty of Technological Management and Innovations, Department of \\ Economics and Strategic Management, Kronverksky avenue 49, Saint Petersburg, 197101, Russia \\ ${ }^{3}$ Professor of Economics, State University of Aerospace Instrumentation, Institute of \\ Entrepreneurship Technologies, Head of Department of High-Tech Sistems Security, Bolshaya \\ Morskaya str. 67, Saint Petersburg, 190000, Russia \\ ${ }^{4}$ Saint Petersburg State University, Faculty of Economics, Department of Economics and Economic \\ Policy, Tchaikovskogo str. 62, a. 310, Saint Petersburg, 191194, Russia \\ azhulega@mail.ru, bnata_c@bk.ru, ${ }^{\mathrm{c} a}$ __samoylov@mail.ru, ${ }^{\mathrm{d} a-n o v i k o v 08 @ m a i l . r u ~}$ \\ *Corresponding author
}

Cite as: Zhulega, I.A., Gagulina, N.L., Samoylov, A.V., Novikov, A.V. (2019). Problems of corporate economics and sustainable development in the context of the sanction world order: Living standards and live quality, Ekonomicko-manazerske spektrum, 13(1), 83-95.

Available at: dx.doi.org/10.26552/ems.2019.1.83-95

\begin{abstract}
It is becoming more difficult for the economy to enter the predicted development trends under conditions of the global systemic crisis, which has become a source of serious problems for countries that are deeply integrated into the world economy. The use of wellknown decision-making mechanisms for a wide range of problems, such as unsustainable consumption and production patterns, poverty and hunger, gender inequality, inequalities between countries and within countries, ecosystem disruption and a number of other equally important problems deserve additional reflection and analysis. In the context of the issues covered in the article, it is especially relevant to analyse the simultaneous impact on the economy of sustainable development mechanisms, based primarily on the objectives of declarative character and practice-oriented economic sanctions. The interrelation of diametrically opposed instruments of global influence that regulate the "scale" of the modern world economy in an attempt to improve its stability is described in the article. Economic sanctions and instruments of sustainable development, methods of corporate management, direct the modern international institutional mechanism to ensure the stability of economic development and sustainable economic growth. In this regard, the application of both sanctions and mechanisms for sustainable development is getting more and more justified. The authors conducted a systematic analysis of corporate economics and principles of sustainable development against the impact of sanctions; identified the problems of sustainable development caused by the introduction of sanctions that make it difficult to achieve the sustainable development goals in the longer term. Possible ways to solve the identified problems are suggested. We studied the "sanctions - living standard, life quality" relation for the BRICS countries in the period of sanctions against Russia and China. We proposed possible solutions for the problems identified.
\end{abstract}


Keywords: economic sanctions, sustainable development, corporate economics and management, living standards, life quality

JEL Classification: 057, M21, K23, F02

\section{Introduction}

In conditions of economic globalization goods, services, financial capital, information, knowledge, people, ideas freely and quickly overcome administrative and geographical boundaries. The softening of restrictions on the international movement of goods, capital and services, the liberalization of domestic markets and the development of foreign capital markets are accompanied by an explosive-like growth in derivatives of financial and economic instruments and increased competition between markets in the world economy. In global markets, in conditions of global competition, global cooperation is strengthening and making its corrections to current, established world economic relations. Under the influence of the institutional mechanism of international interaction, domestic and international processes are subordinated to common laws; common principles of influence and support are being developed. Economic sanctions, countermeasures are among the widespread and increasingly actively applied measures of influence. Support measures, as a rule, result from the mechanisms of sustainable development, economic mutual assistance. By pursuing the same goal - ensuring the stability of economic development and sustainable economic growth, these measures change the overall state of the economies of countries, which inevitably affects their payment balance. For an economy deeply integrated into the world economic space, it is of particular interest to conduct an assessment of possible effects on the level and quality of life of the population of the simultaneous impact of sanctions and sustainable development mechanisms.

\section{Methodology}

\subsection{Sustainable development goals: challenges and new benchmarks}

The dilemma of macroeconomics, aimed at achieving the economic criterion of optimality - the maximum possible satisfaction of needs with a limited number of resources, has been the driving force of modern concepts of development and otherwise for more than a quarter of a century. The replacement of local economic systems by national economies, which occurred at the end of the 19th century, their subsequent dissolution in the world economic system in the last third of the 20th century, radically changes the relationship between external and internal factors of the national economy development. International economic relations at the present stage have become an important tool for the efficient allocation of resources ensuring economic growth on the scale of the world economy. Therefore, the most important condition for the formation and implementation of the national economic policy is the consideration of priorities and norms of behaviour of the main subjects of the world economic activity.

The institutional mechanism of intercountry interaction that has developed in the world economy through concerted rules of conduct and unified procedures, contributes to increasing the level of integration of the commodity and financial markets, opens up new opportunities for the world community in the field of adoption of coordinated economic and political decisions (Fernando and Jaume, 2016). Sustainable development is one of the paradigms on which the institutional mechanism of intercountry interaction is based. More than a semicentenary existence of the concepts of sustainable development originates in the early 
works of the Club of Rome and finds a modern continuation in the works of J. Forrester, D. Meadows, J. Tinbergen. At the threshold of the 21st century, joint work to ensure the priorities of sustainable development continued within the framework of the Millennium Declaration adopted by the world leaders for the period of 2000-2015. The Declaration guided the world community towards achieving the Millennium Development Goals (MDGs) in eight areas: extreme poverty and hunger, gender equality, infant mortality, maternal health, diseases, the environment and global partnership for development.

Over the past period (compared to the baseline level which represented the indicators since 1990), a significant number of tasks provided in MDG have been resolved. Among the main achievements on the scale of the world economy, the experts identify the reduction in malnutrition from $23.3 \%$ to $12.9 \%$, the increase in the share of literate youth from $83 \%$ to $91 \%$, the reduction in the share of women with unstable employment among the employed by $13 \%$, the decrease in the mortality rate among children under five years from 90 to 43 deaths per 1000 live births, the $45 \%$ reduction in maternal mortality and the rate of deaths from tuberculosis, the increase in the number of people on the planet using tap water to $91 \%$ (Revenko, 2015). Along with the success, there were also unsolved problems, the key among which being the possibility to meet basic needs, namely, the continuing inequality in this area. As the analysis of the concept of "quality of life" shows, inequality in meeting the basic needs of people impedes the development of human potential, increases social tension (Majernik et al., 2017). Being the high-demand mechanism of international cooperation, at present, the sustainable development continues in the form of Sustainable Development Goals (hereinafter the Goals, SDGs). Developed for the period up to 2030, the SDGs are defined on the basis of the UN concept papers: "The Future We Want", "The Agenda for Sustainable Development for the Period to 2030", the Paris Climate Agreement (The Future We Want, 2012, Transformation of Our World, 2015, Adoption of the Paris Agreement, 2015).

In an attempt to overcome the difficulties caused by the problems of monitoring and recording of the results achieved, the UN adopted 17 SDGs and 169 tasks for their implementation (Bobylev and Grigoriev, 2016). Despite a significant increase in the number of goals in the framework of sustainable development, tasks and indicators, the main benchmarks and priorities remain. Table 1 presents the UN SDGs, grouped based on the allocation of socio-ecological and economic priorities for Russia.

Table 1: Grouping the UN Sustainable development goals by main priorities

\begin{tabular}{ll}
\hline Goal & Wording of the SDG \\
$\mathbf{N}$ & Woals withe \\
\hline
\end{tabular}

Goals with the main social priorities

The universal elimination of poverty in all its forms

Elimination of hunger, ensuring food security, improving nutrition and promoting sustainable agricultural development

Ensuring comprehensive and just high-quality education and promoting lifelong learning opportunities for all all and creating effective, accountable institutions at all levels based on broad participation 
Problem of corporate economics and sustainable development in the context of the sanction world order:

Living standards and life quality

Authors: Irina A. Zhulega, Natalya L. Gagulina, Alexandr V. Samoylov, Andrey V. Novikov

Strengthening the means for achieving sustainable development and strengthening the mechanisms of the global partnership for sustainable development

Goals with key environmental priorities

Ensuring availability and rational use of water resources and sanitation for all

Promoting progressive, comprehensive and sustainable economic growth, full and productive employment and decent work for all

Adoption of urgent measures to combat climate change and its consequences

Conservation and sustainable use of oceans, seas and marine resources for sustainable development

Protecting and restoring terrestrial ecosystems and promoting their rational use, rational forest management, combating desertification, terminating and reversal of land degradation and terminating the loss of biodiversity

Goals with key economic priorities

Ensuring universal access to affordable, reliable, sustainable and modern energy sources for all

Creating a stable infrastructure, promoting comprehensive and sustainable industrialization and innovation Ensuring transition to rational consumption and production patterns

Source: compilation by the authors based on Lukashuk (2005)

More than a half of the representatives of the world business community who expressed their opinion regarding the SDG pointed out that the main business priorities lie in the sphere of the Goals with the main environmental priority $(\mathrm{N} \mathrm{8,13)}$ and only SDG N 12 in the sphere of the economy (Fig. 1).

Figure 1: SDG priority for business

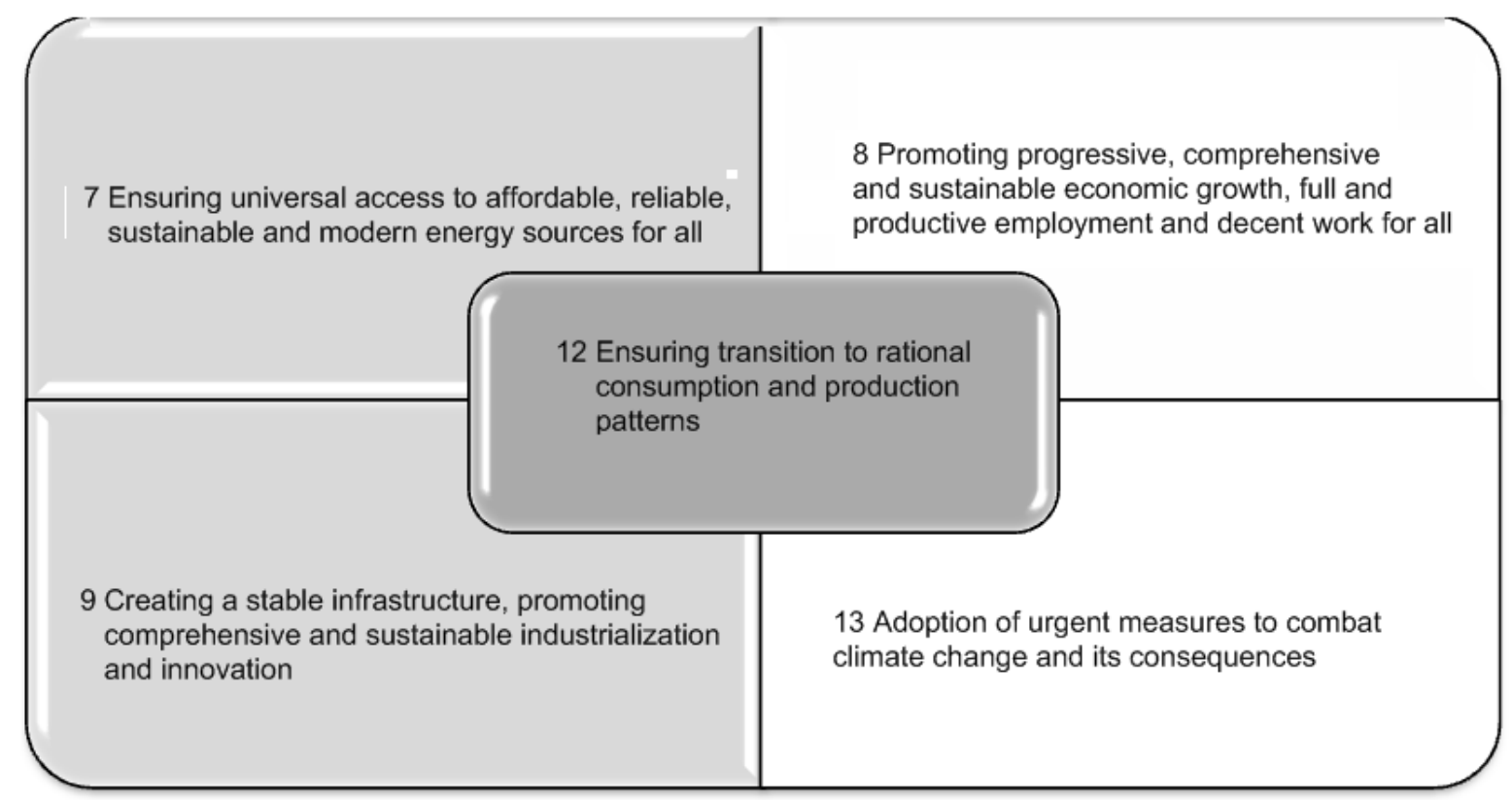

Source: compilation by the authors based on Kokoshin et al. (2005)

For countries with economies in transition and developing countries, the contribution of business communities to the SDG is of great importance, since it helps to reduce the financing shortage for the Goals in conditions of insufficiency and instability of foreign direct investment. Active investment activity is a factor of economic growth and the basis for the economic recovery of any country. In addition to foreign direct investment, the main lines of business participation in the SDG include social investments, combined financing, official 
support and responsible business. Despite the willingness to participate in the implementation of the SDG, in practice, a small part of transnational corporations, banks investment assets, funds and other representatives of international business structures participate in the sustainable development of industries and regions. One of the main reasons is that there are significant risks not only of economic and political nature, such as the crisis in the Euro region, the strong volatility of financial risks and the instability of sovereign borrowers, mainly due to a decrease in energy prices, possible internal conflicts, but also other risks that increase uncertainty for business (Noussair, Trautmann and Van de Kuilen, 2014). The problems of global governance, namely, control over decision-making related to the imposition of sanctions come to the fore, in particular for Russia.

\section{Results}

\subsection{Sanctions, Living Standards and Life Quality}

A living standard is an essential socio-economic category, which characterizes public welfare and is represented by the availability of material and spiritual benefits for people, based on a country's existing demands and level of economic development. As a cumulative characteristic of the country's national wealth, the living standard comprises, along with income and consumption, working and living conditions, amount and organization of working hours and leisure, cultural and educational development parameters, as well as health, sociodemographic and environmental indices within the country and its regions. Therefore, the economic theory and practice usually interpret the living standard as the scope of material benefits and services per capita in a particular period of management. Before we proceed to the analysis of the possible effect of sanctions on the living standards, let us dwell on these concepts.

Sanctions are mainly aimed at limitation of the material consumption and restriction of the citizens' freedoms in the country against which they are enforced. However, the concept of the "country's national living standard" includes not only the scope of material consumption. The need to meet the citizens' cultural (spiritual) and social demands explains the qualitative content of this concept (Mark K. Chan, 2017). As a result, the concept is supplemented by various categories of the reproductive process, new characteristics of working and living conditions. Therefore, the concept of the "living standard" goes hand in hand with such definitions as the "life quality", "cost of living", "lifestyle" and a number of others.

Recently, the concept of "life quality", which has developed on the basis of the concepts of "global employment", "working life quality", etc., has been increasingly used internationally (Lalinska, 2015). The basic and essential components of the "life quality" concept are given in the UN Recommendations. These are health, food consumption, education, employment and labour management, amenities, social security, clothing, leisure, human and, in general, individual rights. Consequently, the concept of the living standard forms a set of conditions, which specify physical, mental and social well-being of an individual, a family or entire social classes and groups of people (Butek, 2015). It takes into account not only objective, common to all people, factors which characterize the life quality and cost of living such as food, housing, workplace, etc., but also an individual's subjective perception of his or her own wellbeing, namely personal achievements, confidence in the future, belief in social justice and equality, life progress, etc.

As the country's living standard is a complex unit with a number of elements, a scorecard has been developed and is used to illustrate its extent and composition. In order to compare the living standards of different countries, as well as to assess the impact of economic policy 
on the life quality, international institutions affiliated with the UN have developed the integral composite human development index (HDI). It is based on the indices of average GDP production, education level, life expectancy and others. Minimum HDI values are close to zero and the maximum to one.

To make commensurate comparisons of the living standards, we will use the statistical data obtained under the UN Development Program in 2018 (UNDP, 2018). Norway, Switzerland, Australia, and Ireland held the top spot in the HDI rating of 189 countries and territories, provided in the 2018 Human Development Reports. HDI values range from zero to one and are the basis to determine a country's position in the rating. The lowest ratings are given to Niger, Central African Republic, South Sudan, Chad and Burundi. The reasons are a small contribution to the human development index of such essential components as national achievements in health and education, and low personal income.

The authors compiled the 2018 human development index data table (table 2) for the BRICS countries, based on the rating under the UN Development Program (UNDP, 2018).

Table 2: Human Development Index and SDG

\begin{tabular}{|c|c|c|c|c|c|c|}
\hline Country & Rank & $\begin{array}{c}\text { Human } \\
\text { Development } \\
\text { Index (HDI) } \\
\text { (value) } \\
\end{array}$ & $\begin{array}{c}\text { Life expectancy } \\
\text { at birth (years) } \\
\text { SDG3 }\end{array}$ & $\begin{array}{c}\text { Expected years } \\
\text { of schooling } \\
\text { (years) SDG } 4.3\end{array}$ & $\begin{array}{c}\text { Mean years of } \\
\text { schooling } \\
\text { (years) SDG } 4.6\end{array}$ & $\begin{array}{c}\text { Gross national } \\
\text { income (GNI) } \\
\text { per capita (PPP } \\
\text { \$) SDG 8.5 } \\
\end{array}$ \\
\hline $\begin{array}{l}\text { Russian } \\
\text { Federation }\end{array}$ & 49 & 0.816 & 71.2 & 15.5 & 12.0 & 24,233 \\
\hline Brazil & 79 & 0.759 & 75.7 & 15.4 & 7.8 & 13,755 \\
\hline China & 86 & 0.752 & 76.4 & 13.8 & 7.8 & 15,270 \\
\hline South Africa & 113 & 0.699 & 63.4 & 13.3 & 10.1 & 11,923 \\
\hline India & 130 & 0.640 & 68.8 & 12.3 & 6.4 & 6,353 \\
\hline
\end{tabular}

Source: compiled by the authors based on (NUMBEO, 2018)

Among the integrated indices used to characterize HDI, we can see several indices for sustainable development goals: life expectancy at birth (SDG 3), expected years of schooling (SDG 4.3), mean years of schooling (SDG 4.6), gross national income (GNI) per capita (SDG 8.5). Among the BRICS countries, Russia holds a leading position, whereas it is ranked 49-th in the overall rating of 189 countries. Russian HDI values are quite high mainly due to the achievements in Russian educational quality. It is difficult to overestimate the contribution by educational institutions to the country's economic development, as it is not only a guaranteed availability of the country's own competent human resources for the current economic demands but also the key to future strategic success. Moreover, a high educational level is traditionally accompanied by a high level of public culture. Thus, it goes without saying that the indices we have considered contributing to the achievement of the sustainable development goals and thus influence the country's living standard and life quality. (Grechenyuk, Grechenyuk and Polyanin, 2016). However, these indices are not sufficient to make a judgment on the impact of sanctions on the prospects for economic growth and development, the future life quality or the living standard of individual economic entities and their groups.

Some idea of the impact of sanctions on the living standard of an individual, a social, regional or ethnic group and overall population may be derived from a scorecard focused on such human values as health, safety and their economic security. First of all, it is the consumption fund size which depends on the GDP and its distribution, per capita within the 
country and the region. In addition, it is the nominal and real income level, availability of housing, utilities and social services, as well as of the educational, health, information and transport services. The living standards scorecard created this way gives an idea of what the average personal income is, and to what extent it covers the material and spiritual needs of people (Falk et al., 2018). The scorecard makes it possible to compare and contrast the living standards both over time, i.e. their progress, and in the administrative and territorial context, between social and regional groups and population of different countries.

The living standard scorecard would be incomplete without indices describing the personal income, its level, development, differentiation, as well as the relation between income and subsistence rate. The personal income, together with the actual end use of material goods and household services, form the basis of the entire living standard scorecard. The country's cash and real income indices are distinguished in the living-standard economic scorecard, which should be taken into account in the analysis of how sanctions affect the life quality (Altunyan and Kotsofana, 2016). Personal cash income includes the income of individuals engaged in entrepreneurship, wages paid, social benefits (pensions, allowances, scholarships, insurance indemnities and other payments), property income as deposit, security interests, dividends, and other income. Real income consists of available cash income retained by households after mandatory payments and contributions have been deducted. It is difficult to form a view of the people's purchasing power exclusive of income.

Such a somewhat generalizing index as the per capita consumption fund is of great importance for comparisons at the international level. The ratio between the average per capita and low-level incomes and the subsistence rate, as well as that between the data on the size and rate of population within the poverty line is of exceptional importance for the socioeconomic analysis, life quality assessment of the population and its social and territorial groups, for the country's social policy development.

In addition to the income level and material consumption, the living standard largely depends on the housing availability for the public. This is all the more important since the marginal propensity to consume from temporary income increases the cost of housing (Berger et al., 2018). This index is of particular value for people of those countries where most of them live in municipal apartments paid for on preferential terms. In different countries, the housing conditions are described by various indices: the number of bedrooms, area, etc. In Russia, for instance, there is an index for the availability of housing with shared or living space per capita. Globally, the calculation of the property price-to-income ratio is applied.

The living standard and life quality indices are interrelated and have a mutual influence by increasing or decreasing the level of any given index. For instance, if young people's demands for general and vocational education are met more fully, this ensures the skill raising and, therefore, should the skills meet an industry's needs, this ensures income and consumption growth. Similarly, improved health care, increased availability of health service for the general public contributes to better health and influences not only demographic indices but also the increase in labour intensity, productivity and income. In turn, the personal income growth ensures the demands in education, medical service - with regard to fee-based ones to be better met. (Kojima, Pathak and Roth, 2013). We will use the life quality values given in the world's largest Numbeo database (NUMBEO, 2018) for further comparative analysis. According to the calculation results, the life quality index is scaled within a wide range, which changes routinely, by linear scaling. For this purpose, they identify the reference points (maximum and minimum index values) which show the real index position for each specific region in the common space. For the basis of an assessment of the quality of life, which is received with the use of empirical formula, eight various criteria are accepted. The criteria 
include the cost-of-living index, purchasing power index, environmental pollution index, estimated ratio of property (housing) price to income, safety index, health index, travel time index, and climate index.

In order to analyze the possible impact of sanctions on the life quality of the countries against which they have been enforced, two annual intervals have been chosen pointwise - the one prior to the enforcement of sanctions and the one after the sanctions have taken effect. Tables 3 and 4 show the life quality values, taken by the authors from the Numbeo database in 2012 and 2017, respectively.

\begin{tabular}{|c|c|c|c|c|c|c|c|c|c|}
\hline Country & $\begin{array}{l}\text { Country's } \\
\text { position in } \\
\text { the rating of } \\
51 \text { countries }\end{array}$ & $\begin{array}{l}\text { Purchasing } \\
\text { Power } \\
\text { Index }\end{array}$ & $\begin{array}{l}\text { Safety } \\
\text { Index }\end{array}$ & $\begin{array}{l}\text { Health Care } \\
\text { Index }\end{array}$ & $\begin{array}{l}\text { Cost of } \\
\text { Living } \\
\text { Index }\end{array}$ & $\begin{array}{l}\text { Property } \\
\text { Price to } \\
\text { Income } \\
\text { Ratio }\end{array}$ & $\begin{array}{c}\text { Traffic } \\
\text { Commute } \\
\text { Time Index }\end{array}$ & $\begin{array}{l}\text { Pollution } \\
\text { Index }\end{array}$ & $\begin{array}{c}\text { Quality of } \\
\text { Life Index } \\
\text { (2012) }\end{array}$ \\
\hline $\begin{array}{l}\text { South } \\
\text { Africa }\end{array}$ & 25 & 99,97 & 21,88 & 59,54 & 76,89 & 2,99 & 34,50 & 88,96 & 83,59 \\
\hline India & 33 & 62,05 & 54,36 & 59,42 & 34,28 & 9,80 & 48,33 & 102,91 & 44,01 \\
\hline Brazil & 44 & 31,73 & 40,74 & 59,09 & 87,64 & 15,28 & 30,00 & 82,92 & 10,81 \\
\hline Russia & 47 & 44,05 & 49,43 & 35,52 & 69,37 & 14,41 & 47,83 & 104,67 & $-7,39$ \\
\hline China & 51 & 33,50 & 55,53 & 36,15 & 51,63 & 29,90 & 29,67 & 122,80 & $-49,55$ \\
\hline
\end{tabular}

Source: compilation by the authors based on (NUMBEO, 2018)

Table 4: Quality of Life Index, 2017

\begin{tabular}{|c|c|c|c|c|c|c|c|c|c|c|}
\hline Country & $\begin{array}{c}\text { Country's } \\
\text { position } \\
\text { in the } \\
\text { rating of } \\
67 \\
\text { countries } \\
\end{array}$ & $\begin{array}{l}\text { Purchasing } \\
\text { Power } \\
\text { Index }\end{array}$ & $\begin{array}{l}\text { Safety } \\
\text { Index }\end{array}$ & $\begin{array}{c}\text { Health } \\
\text { Care } \\
\text { Index }\end{array}$ & $\begin{array}{l}\text { Cost of } \\
\text { Living } \\
\text { Index }\end{array}$ & $\begin{array}{c}\text { Property } \\
\text { Price to } \\
\text { Income } \\
\text { Ratio }\end{array}$ & $\begin{array}{c}\text { Traffic } \\
\text { Commute } \\
\text { Time } \\
\text { Index }\end{array}$ & $\begin{array}{l}\text { Pollution } \\
\text { Index }\end{array}$ & $\begin{array}{c}\text { Climate } \\
\text { Index }\end{array}$ & $\begin{array}{c}\text { Quality } \\
\text { of Life } \\
\text { Index } \\
(2017)\end{array}$ \\
\hline $\begin{array}{l}\text { South } \\
\text { Africa }\end{array}$ & 32 & 98,96 & 24,28 & 61,72 & 43,12 & 3,58 & 42,98 & 63,56 & 88,74 & 144,72 \\
\hline India & 51 & 76,73 & 56,04 & 69,18 & 25,08 & 10,28 & 46,38 & 76,53 & 9,3 & 101,52 \\
\hline Brazil & 53 & 42,38 & 29,38 & 51,7 & 53,07 & 16,96 & 46,39 & 61,17 & 70,76 & 96,15 \\
\hline China & 57 & 67,84 & 66,1 & 62,25 & 44,76 & 23,29 & 43,87 & 88,96 & 38,7 & 90,95 \\
\hline Russia & 61 & 48,27 & 53,95 & 56,4 & 42,01 & 13,55 & 48,57 & 63,04 & 10,69 & 85,93 \\
\hline
\end{tabular}

Source: compiled by the authors based on (NUMBEO, 2018)

The 2012 rating was headed by Switzerland having the maximum life quality value of 194.11, and rounded out by China (-49.55). In 2017, the range of life quality values varied from 190.37 (Austria) to zero (Venezuela). The contribution of each criterion to the estimated value of life quality is determined by the nature of the "life quality - index" relation (table 5). Therefore, the results obtained in 2017 can be explained not only by improved life quality, but also by the significant contribution to the life quality, which is accounted for by the climate factor. The 2012 values of the life quality index are given exclusive of the climatic factor.

Table 5: Relation to the Life Quality Index

\begin{tabular}{|c|c|c|c|c|c|c|c|c|}
\hline Index & $\begin{array}{c}\text { Purchasing } \\
\text { Power } \\
\text { Index }\end{array}$ & Safety & Health & $\begin{array}{l}\text { Cost of } \\
\text { Living } \\
\text { Index }\end{array}$ & $\begin{array}{c}\text { Property } \\
\text { Price to } \\
\text { Income } \\
\text { Ratio }\end{array}$ & $\begin{array}{c}\text { Traffic } \\
\text { Commute } \\
\text { Time } \\
\text { Index }\end{array}$ & Pollution & Climate \\
\hline
\end{tabular}




\begin{tabular}{|c|c|c|c|c|c|c|c|c|}
\hline $\begin{array}{c}\text { Relation to } \\
\text { the Life } \\
\text { Quality }\end{array}$ & direct & direct & direct & inverse & inverse & inverse & inverse & direc \\
\hline $\begin{array}{c}\text { Index } \\
\text { (Contributio } \\
\mathrm{n})\end{array}$ & $(+)$ & $(+)$ & $(+)$ & $(-)$ & $(-)$ & $(-)$ & $(-)$ & $(+)$ \\
\hline
\end{tabular}

Source: compilation by the authors based on (NUMBEO, 2018)

To be sure, the life quality of the BRICS group has improved over the past 5 years (figure 2).

Figure 2: Life Quality of the BRICS Group

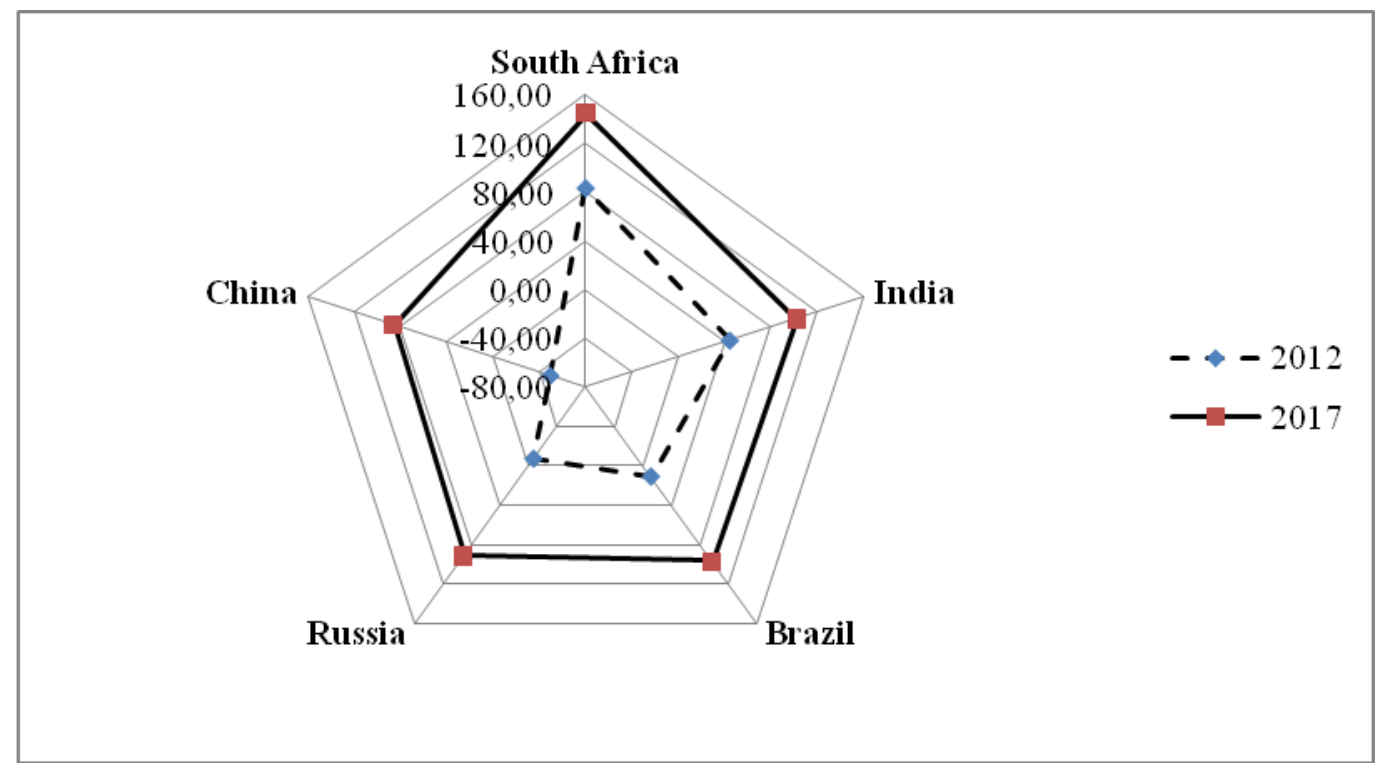

Source: compilation by the authors based on (NUMBEO, 2018)

China has shown a major breakthrough in improving life quality over the past 5 years. The result can be explained by a more than twofold increase in the national purchasing power, a significant increase in the health indicator and, at the same time, a reduction in the environmental pollution index (figure 3).

Figure 3: Life Quality of China

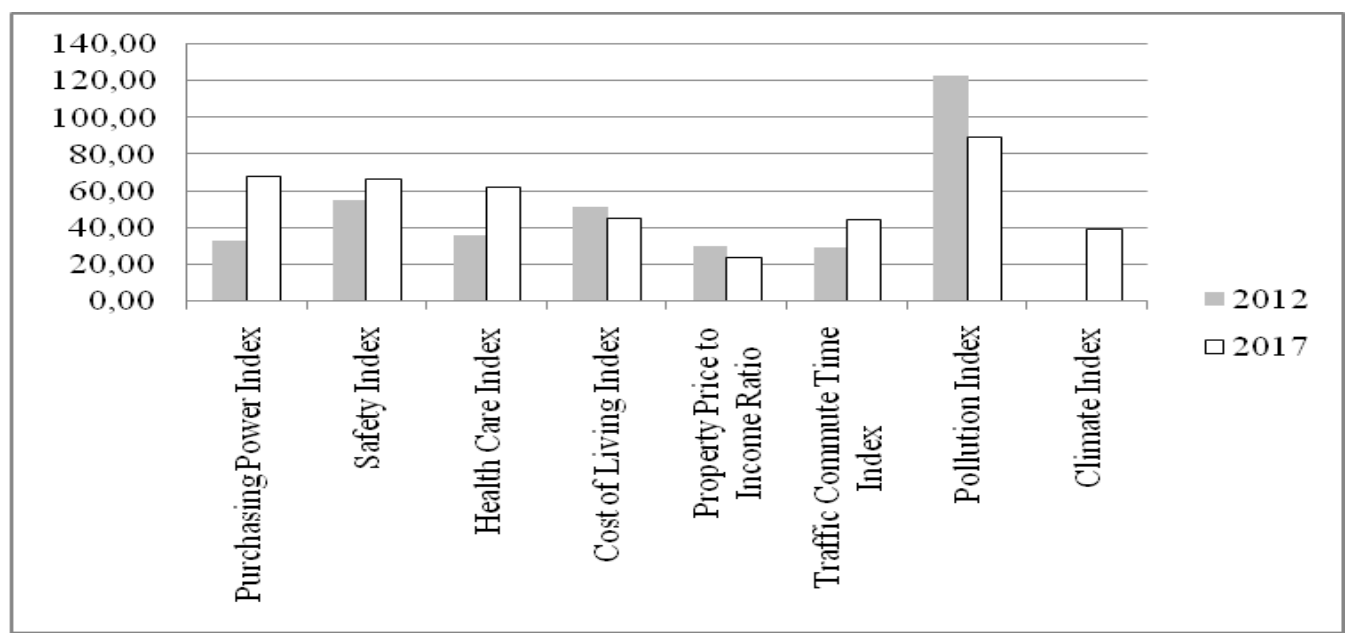

Source: compilation by the authors based on (NUMBEO, 2018) 
Russia has also shown significant progress in upgrading the life quality (figure 4).

Figure 4: Life Quality of Russia

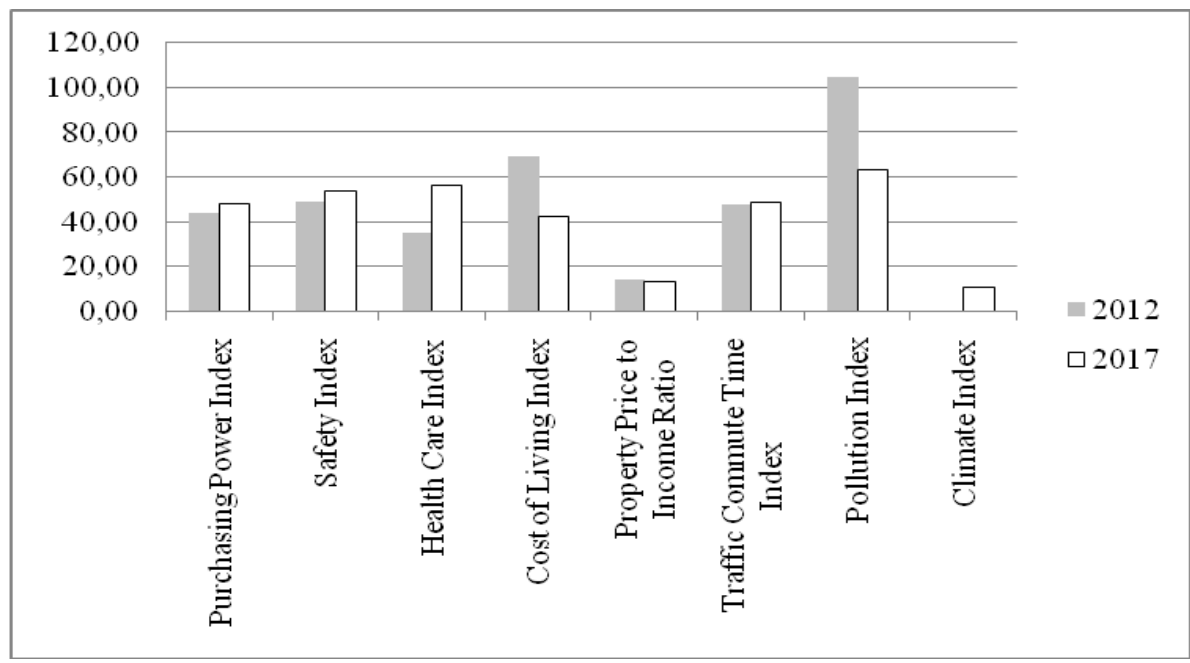

Source: compilation by the authors based on (NUMBEO, 2018)

The improvement in Russia's life quality is due to all the factors combined: the cost of living has dropped, safety has improved, and the indices describing the public health situation have increased in the context of the growth of the national purchasing power. Travel time has slightly increased, which indicates a reduced efficiency of the infrastructure. The environmental situation has improved, as evidenced by the reduced environmental pollution; the climate index has made a positive contribution as well. The stable ratio of housing prices to personal income is explained by recessions in the Russian estate market.

\subsection{Achievability of sustainable development goals in condition of sanctions}

The term "sanction" is used to refer to coercive measures taken by international organizations, based on Chapter VII of the UN Charter (Lukashuk, 2005). Economic sanctions, like the mechanisms of sustainable development, are aimed at maintaining or restoring international peace and security. Considering sanctions as a method of more effective and humane compulsion than an armed conflict, the UN Security Council applies them as an alternative to an armed conflict (Gracheva, 2017). The sanctions against Iraq were aimed at the unarmed, peaceful settlement of international disputes in the Persian Gulf zone. The introduction of economic sanctions is provided for in the Article 41 of the UN Charter and, in the event of a complete or partial break in economic relations, it entails trade and financial sanctions. Sanctions can be an extremely painful measure not only for countries with economies in transition, developing countries but also for the economies of the world's leading countries. In recent decades, the world GDP, the volume of the industry, investment, trade, technology transfer are growing at an accelerated pace. Therefore, in the context of globalization, even countries with a self-sufficient resource base, a significant intellectual potential, developed industry and a large sales market, pursuing a relatively independent economic policy, demonstrate the dependence of the domestic economy on international exchange of goods. Various spheres of life-sustaining activities of the society primarily economy and politics appear to be under the influence of the effects of the introduction of sanctions (Padro i Miquel, 2007). A partial or complete embargo involves restricting the supply of goods to the country in respect of which it is imposed, and it inevitably leads to a change in trade policy, even if the embargo is applied only to the supply of arms to the target 
country. There is an increase in prices for food and non-food products, a decrease in aggregate demand, a reduction in travel abroad and a crisis of small businesses (Nureev and Petrakov, 2015). Health care, provision of food appears to be under the impact. In this sense, the example of Iraq is indicative, when the civilian population of the country suffered from the systematic use of low-quality food, a shortage of drinking water, and a shortage of medications, which triggered the growth of diseases and the spread of infections (Popal, 2000). Aimed at fighting the military actions in the Persian Gulf, the sanctions against Iraq proved destructive for the country's economy. The civilian population suffered, as evidenced by an "increase in the mortality rate among children under 5 years by more than two times, in total resulting in the death of more than 500,000 children between 1991 and 1998 from malnutrition, the lack of medicine, clean water and otherwise" (Bratersky, 2009). There are other examples of the multiple impacts of sanctions on the economy of the target country: a long regime of sanctions against Iran, the US sanctions against Cuba, collective sanctions against South Africa, Haiti, etc. The financial sanctions, applied along with the trade ones, have no less destructive consequences for the domestic economy of the target country. They impose restrictions on contacts with financial organizations, the implementation of financial transactions and are aimed at a narrow subject matter, i.e. at specific individuals and their property. The most common forms of financial sanctions include blocking foreign assets and stopping the provision of financial assistance. Influencing the state of the economy of the target country, the sanctions lead to a fall in GDP, worsen the investment attractiveness and suppress innovation activity, reducing the level of technology development in the long term. Having compared the consequences of imposing economic sanctions and the Millennium Development Goals and the Sustainable Development Goals, one can view sanctions as a counterbalance to the mechanism of sustainable development (Table 6).

Table 6: Millennium Development Goals and the Sustainable Development Goals

Goal N Wording of the SDG Accompanying result from imposed sanctions in the
target country

The rise in prices, the fall in GDP (in Angola and Zimbabwe: from \$

The universal elimination of poverty in all its forms

2

3

10

Reducing inequalities within and between countries

12

Elimination of hunger, ensuring food security, improving nutrition and promoting sustainable agricultural development

Providing a healthy lifestyle and promoting well-being for all at any age

Ensuring transition to rational consumption and production patterns

Problems in healthcare and provision of food (Shah, 2017, Meller and Litschig, 2014, Akbulut-Yuksel, 2014, Guthmuller, Jusot, and Wittwer, 2014)

The threat to the well-being of the population (the sanctions imposed on Iraq and Haiti were implemented without violent intervention) (Kokoshin, 2005)

The introduction of any restrictive measures, including sanctions, a priori puts the target country in an unequal position in comparison with other countries (Bierbrauer, 2016, Boffa, Piolatto and Giacomo, 2016, Gilbert, 2012)

Sanctions have a negative impact on foreign direct investment, which could be involved in the construction of specified models (in

1985 , the outflow for Iran was $\$ 38.15$ million and almost $\$ 362$ million in 1990) (Nureev and Busygin, 2017, Betermier and Laurent, 2017)

Source: compilation by the authors based on (Nureev and Busygin, 2017, Shah, 2005, Nureev and Busygin, 2017, Kokoshin, 2005) 
In connection with the inertia of macroeconomic processes, the prohibitive measures due to the imposition of sanctions act as constraints that hold down or even block sustainable development, not only in the period of validity but also in the long term, after they are lifted (Martin, Mayer and Thoenig, 2008).

The study showed that the impact of sanctions is poorly marked in the selected field of study. The national living standard and life quality are more influenced by macroeconomic factors and public policy tools than by external international pressure.

\section{Discussion and Conclusion}

To minimize the associated undesirable effects of economic sanctions, a methodical effort to develop an adaptation strategy seems appropriate for the target country. An integrated approach, which combines science, finance, and technologies, to the development and implementation of measures to adapt the economy to the sanctions imposed at the regional and sector-based levels will help reduce the vulnerability of the economy and the public. In this, a special role is given to the formation of a productive institutional balance, which will create the background and conditions for economic growth and sustainable development.

Great potential for mutually beneficial open cooperation can be seen within the international regional associations. A good example is the group of BRICS countries, which have shown positive changes in life quality over the past five years, including in achieving the planned Sustainable Development Goals.

Funding: This research received no external funding

Author Contributions: All authors listed have made a substantial, direct and intellectual contribution to the work, and approved it for publication.

Conflict of Interest Statement: The authors declare that the research was conducted in the absence of any commercial or financial relationships that could be construed as a potential conflict of interest.

\section{References}

Adoption of the Paris Agreement. (2015). Conference of the parties. Twenty-first session. Paris, November 30 December 11, 2015. The United Nations Framework Convention on Climate Change. The UN.

Akbulut-Yuksel, M. (2014). Children of war: The long-run effects of large-scale physical destruction and warfare on children. Journal of Human Resources, 49(4407).

Altunyan, A. \& Kotsofana, T. (2016). Global political and economic processes, monetary policy of the bank of Russia and development of the Russian economy. Proceedings of the $16^{\text {th }}$ International Scientific Conference of Globalization and its Socio-Economic consequences, Rajecke Teplice, Slovakia, 33-40.

Berger, D., Guerrieri, V., Lorenzoni, G. \& Vavra, J. (2018). House prices and consumer spending. The Review of Economic Studies, 85(3), 1502-1542.

Betermier, S., Laurent, C. E. \& Sodini, P. (2017). Who are the value and growth investors? Journal of Finance, 46(3), 1011-1041.

Bierbrauer, F. J. \& Boyer, P. C. (2016). Efficiency, welfare, and political competition. The Quarterly Journal of Economics, 131(1), 461-518.

Bobylev, S. N. \& Grigoriev, L. M. (2016). Sustainable development goals of the United Nations and Russia. Report on human development in the Russian Federation for 2016. Moscow: Analytical Center under the Government of the Russian Federation.

Boffa, F., Piolatto, A. \& Giacomo, A. (2016). Political centralization and government accountability. The Quarterly Journal of Economics, 131(1), 381-422. 
Bratersky, M. V. (2009). Trade and economic sanctions: Efficiency, price, problems of use. The Security of Eurasia, 2(36), 335-347.

Butek, M. (2015). Importance of local structures in the globalized world. Proceedings of the $15^{\text {th }}$ International Scientific Conference of Globalization and its Socio-Economic consequences, Rajecke Teplice, Slovakia, 7277.

Chan, M. K. (2014). Welfare dependence and self-control: An empirical analysis. The Review of Economic Studies, 84(4), 1379-1423.

Falk, A., Becker, A., Dohmen, T., Enke, B. \& Huffman, D. (2018). Global evidence on economic preferences. The Quarterly Journal of Economics, 133(4), 1645-1692.

Fernando, B. \& Jaume, V. (2016). Rethinking the effects of financial globalization. The Quarterly Journal of Economics, 131(3), 1497-1542.

Gilbert, M. (2012). Reconciliation of domestic and international objectives of financial policy: European Countries. Journal of Finance, 174 - 186.

Gracheva, A. M. (2017). Concept and types of economic sanctions in international law. Proceedings of the Institute of State and Law of the Russian Academy of Sciences, 159-171.

Grechenyuk, O., Grechenyuk, A. \& Polyanin, A. (2016). Research of global servicization processes and their role in the Russian economy. Proceedings of the $16^{\text {th }}$ International Scientific Conference of Globalization and its Socio-Economic consequences, Rajecke Teplice, Slovakia, 523-531.

Guthmuller, S., Jusot, F. \& Wittwer, J. (2014). Improving take up of health insurance program: A social experiment in France. Journal of Human Resources, 49(1), 167-194.

Kojima, F., Pathak, P. A. \& Roth, A. E. (2013). Matching with couples: Stability and incentives in large markets. The Quarterly Journal of Economics, 128(4), 1585 - 1632.

Kokoshin, A. A. (2005). The world politics: Theory, methodology, applied analysis(http://www.obraforum.ru/Mirovaja_politika/chapter11.htm).

Lalinska, J. (2015). Comparison of information quality methodologies. Proceedings of the 15th International Scientific Conference Globalization and Its Socio-Economic Consequences, Rajecke Teplice, Slovakia, 362370.

Lukashuk, I. I. (2005). International law. General part: Textbook for students of law schools and faculties. 3th edition. Moscow.

Majernik, M., Andrejovsky, P., Sanciova, G. \& Repkova-Stofkova, K. (2017). Evaluation of "green" business growth and economy in Slovakia using international indicators. Proceedings of the 17th International Scientific Conference Globalization and Its Socio-Economic Consequences, Rajecke Teplice, Slovakia, 3340.

Martin, P., Mayer, T. \& Thoenig, M. (2008). Make trade not war? The Review of Economic Studies, 75(3), 865900.

Meller, M. \& Litschig, S. (2014). Saving lives: Evidence from a conditional food supplementation program. Journal of Human Resources, 49(4), 1014-1052.

Noussair, C. N., Trautmann, S. T. \& Van de Kuilen, G. (2014). Higher order risk attitudes, demographics, and financial decisions. The Review of Economic Studies, 81(1), 325-355.

Nureev, R. \& Busygin, E. (2017). Economic sanctions: Costs and benefits of confrontation. Terra Economicus, 15(3), 56-74.

Nureev, R. M. \& Petrakov, P. (2015). Ordinary consumer: The burden of economic sanctions against Russia. Journal of Economic Regulation, 6(3), 40-60.

NUMBEO Quality of Life Index for Country 2012 (https://www.numbeo.com/quality-oflife/rankings_by_country.jsp?title=2012-Q1).

Padro i Miquel, G. (2007). The control of politicians in divided societies: The politics of fear. The Review of Economic Studies, 74(4), 1259-1274.

Popal, G. R. (2000). Impact of sanctions on the population of Iraq. Eastern Mediterranean Health Journal, 6(4), 791-795.

Revenko, L. (2015). Sustainable development: Results of implementation of the global program Expert of the Moscow State University of Foreign Affairs: Liliya Revenko, Doctor of Economics, professor http://oxfam.ru/news/368/ (published on July 16, 2015).

Shah, A. (2017). Effects of Iraq Sanctions. Global Issues, October 2; Web. October 7. (http://www.globalissues.org/article/105/effects-of-sanctions).

UNDP Human Development Indices and Indicators. 2018 Statistical Update// Published for the United Nations Development Programme (UNDP) (http://hdr.undp.org/en/2018-update). 